\title{
The Tunisians Cooperative Teachers and Student Teachers' Conceptions about Class Management Skill
}

\author{
Naila Bali1,2 \\ ${ }^{1}$ High Institute of Sport and Physical Education, Ksar Saïd, University la Manouba, UMA, Tunis, Tunisia \\ ${ }^{2}$ Tunisian Research Laboratory Sport Performance Optimization, Tunis, Tunisia \\ Email: naila_bali@yahoo.fr
}

Received 3 January 2015; accepted 21 January 2015; published 27 January 2015

Copyright (c) 2015 by author and Scientific Research Publishing Inc.

This work is licensed under the Creative Commons Attribution International License (CC BY). http://creativecommons.org/licenses/by/4.0/

(c) $\underset{\mathrm{EY}}{\mathrm{B}}$ Open Access

\section{Abstract}

The first teaching year is a crucial time for professional growth and teacher development requiring pedagogical and emotional support from a qualified mentor. According to Ingersoll (2003), $46 \%$ of all teachers in public schools will leave the profession within their first five years of teaching. Until 1990, there was a considerable discussion about how the novice teachers can develop more competence. There has been limited empirical research on the effectiveness of physical education student teacher (PESTT), particularly as they relate to teaching. The aim of this research is to study the conceptions of Authority of Tunisian High School Physical Education Cooperative teachers and student teachers. The method used in the quoted investigation is based on directing a semi-directive interview with 10 mentors and their PESTT (24) in the initiation of practical pedagogy, at the Higher Institute of Sport and Physical Education (ISSEP) Ksar Saïd Tunis. The PESTT were teaching at a school in Tunis with mixed classes (aged 12 - 14). Data were collected from monitor interviews, PESTT interviews, observations and analysis of the PESTT teaching. Data analysis occurred, through the efforts of the teacher-researcher to meet the "on the spot" learning needs of his students; the systematic collection, organisation and analysis of the gathered data; and the peer debriefing, which occurred throughout the collection and writing processes. Two tendencies of unequal importance were constructed from analysis of data sources according to mentor reflections: a majority teacher-centred pedagogy $(77 \%)$ and a minority student-centred pedagogy (22\%). A number of themes emerged from the analysis of each case. These themes are discussed within the data resources from PESTT of how their perceptions of authority. This study shows that the commonly perception of mentors about their PESTT is negative. However, the findings of this study support the idea that PESTT can not well manage the indiscipline behaviour of their pupils and are not able to think about real reason of this problem. 


\section{Keywords}

\section{Mentors, Physical Education, Student Training Teacher, Authority, Internship}

\section{Introduction}

Management class in high school is a complex, dynamic and multidimensional nature (Duke, 1982; Good \& Brophy, 1987). Because of this complexity, it is seen firstly as one of the biggest problems of new and experienced teachers (Cruickshank, Kennedy, \& Meyers, 1974; Veenman, 1984), which has led many scholars to propose that it be formally included in the initial training programs (Ministry of Education of Quebec, 1992; Pigge, 1978). Because of the need for an improvement of the quality of the school and its efficiency (Creemers et al., 1989), there is a demand for more teachers efficient and better "management" classes (Brophy \& Good, 1986). This phenomenon has been accentuated, by the results of research in science education that confirmed the hypothesis that "the efficiency" of school depend on the teachers' activity efficiency in their classrooms (Mullens, 1996; Turner \& Meyer, 2000). Teachers' confidence in their capacity to achieve the actions that lead to student learning is one of the few individual characteristics that consistently predict the practice of teachers and students learning (Ross, 1994; Woolfolk \& Hoy, 1990). Therefore, student teaching has been regarded as the most influential factor in teacher education programmes (Hoy \& Woolfolk, 1989; Wilson, 2006). The core activities of teaching occur in real time, involve social and intellectual interactions, and are shaped by the students in the environment, thus increasing the complexity of the task (Leinhardt, 2001). The theoretical framework for this study draws from research establishing the complex nature of teaching and, consequently, the challenges of mentoring teaching practices. According to MacKinnon (1987); based on the work of Fuller and Brown (1975); four types of concerns affecting successively beginning teachers during their initial training and early career. Firstly, before their first teaching experience, they have difficulties in identifying the role of teacher. Later, their first contact with students affects their immediate survival as professionals. Then confronted with the limits of their intervention, beginning teachers tend to focus primarily on issues of approaches and methods. Finally, having overcome the initial hurdles, they arrive gradually became interested in their practice, the quality of learning and social and emotional needs of their students.

Regarding discipline, two contradictory objectives perceived concern beginning teachers: properly control their class and be appreciated by their students (Fuller \& Brown, 1975). That is why they will try to solve this dilemma is by using a freind-freind approach or by adopting an authoritarian attitude, rather than adopting a preventive management based on rules (Johnson, 1993).

In contrast to process-product research in which effective teaching could be attributed to discrete, observable teaching, the mentor who supervises the student teacher has the most essential and influential role in this process. A successful student teaching experience often requires a series of facilitating attitudes and behaviours on the part of the mentoring teacher (Kim \& Danforth, 2012). Thus, cooperating teachers' beliefs of effective supervision of student teachers may play an important role in mentoring practices. Unconsciously expressed in the discourse of cooperating teachers concerning supervision of student teachers, these beliefs could be made explicit (Kim \& Danforth, 2012). If mentoring is to function as a strategy of reform, it must be linked to a vision of good teaching, guided by an understanding of teacher learning, and supported by a professional culture that favours collaboration and inquiry. So, the assessment of teaching practice continues to be a significant issue for teacher education programs. One specific relationship that has gained attention in school supervision literature is the benefit of an assigned and effective mentor (e.g., Herbert \& Ramsey, 2004; McCormack et al., 2006; Odell \& Ferraro, 1992).

\section{Integration of Novice Teacher in Physical Education (PE)}

Several studies focused on the professional socialization of teachers showed that the beginning of the career is a determinant internship (Zeichner \& Gore, 1990). Because of his status, the physical educational student teacher training (PESTT) is in a paradoxical situation where he must build an adequate and functional representation about his work environment and this, not from a student's conception (because he is yet) but from that of a teacher (that he is currently becoming). In this way, professional insertion is a veritable identity transformation 
process (Martineau \& Corriveau, 2000). However, the entry into the teachers' career represents generally a "choc reality" (Martineau, 2003). The PESTT is face to a double challenge. First, he must adjust or increase rapidly several knowledges (Tardif \& Lessard, 1999) and many skills to increase the real situation of intervention in which he is. On the other side, he must assimilate his trainer advices, who ensure his accompaniment during the internship period. This double challenge can easily bring him to behave a traditional and somewhat innovative conduct, and submit him to the conformity pressure coming from the world of work (Martineau, 2003). Situated in the particular field of teaching physical education and sports, where the competence of knowledge transmission joins the absolute responsibility of maintaining students' safety, as well as the control of the different types of working groups, authority occupies a predominant topic in the relationship unifying the teacher to his class (Dussaussois, 1997). Indeed, Hubert said that "pedagogy is a mixture of art and science" (Hubert, 1952). He puts forward that there are two complementary aspects: 1) A personal aspect: personal charisma, attention and listening capacity, enthusiasm... 2) A scientific and technical aspect: mastery of the discipline, didactic of the discipline, teaching organisation... However, the class management in secondary education is a complex, dynamic and multidimensional activity (Duke, 1982; Good \& Brophy, 1987). Because of this complexity, it is perceived on the one hand as one of the biggest problems of beginning teachers and even experienced (Cruickshank, Kennedy, \& Meyers, 1974; Veenman, 1984) and present a professional teaching obstacle, on the other hand (Michaud \& Alin, 2009). Several studies have shown that beginning teachers met more discipline problems than the most experienced (Martineau, 2003). And if there is no discipline or attention during a Physical Education Session (PES), not only teaching can not be provided but learning becomes problematic. So, in a session of physical education, there are all the acts favouring the order and the organization ensuring the optimum conditions for teaching and learning: rules, sanctions, values, learning climate... are found preoccupations in the technical acts. The symbolic challenge reside in the ability to obtain an order perceived as necessary and legitimate by all the actors of the teaching situation. More concretely, teacher authority is the result of students' recognition of the skills he displays in action. Such skills pass inevitably trough the operationalization of its disciplinary, pedagogical and relational knowledge's. According to Robbes (2006) authority results from construction of knowledge during teaching practice. However, novice teacher is confronted to resolve the problem how to mange indiscipline and what knowledge helping him to do it

"Teacher authority is not natural but (....) results from a knowledge construction in action. The teacher is faced to the nagging question of 'how to do?' that is to say to the actions knowledge's that it engages in the practice of educational authority” (Robbes, 2006).

Furthermore, because of the discipline's originality, in a PES, different actors (Robbes, 2006) act and are engaged in ongoing local interactions such as: laying out of the field, displacement on the field, help a pupil in difficulty, perform parades, manipulate a student, give instructions to a small working group, speak to the entire class, (while some students work in sub-groups organized on their way, others are in the process of discussing an extra-school subject), the teacher's mission becomes more difficult, especially when it's about the beginners. Do not forget that these situations present a freedom opportunity for some students (Robbes, 2006). Piot (2008) and Vanderstaa \& All (2009) believe that the authority was strongly based in the teacher's professionalism as a skill more than his bureaucratic or charismatic influence.

In Tunisia, the university education aims to help PE-STs into internship working (Bali et al., 2014). For this reason the trainee is the central actor in his own training; it is not isolated to the master of the course but surrounded by cooperative teachers.

The role of the master course is the hold of the student, but a large number of actors involved, formally or informally, with his training. The difficult that PE-STs faced was how to mange authority into the course by acting as a teacher and comply with its status as a student (Bali, 2013).

However, in Tunisia no study was reported this paradigm. Until now, no study examined the insufficiency and the increasing complexity of the subject matter of authority research coupled with the relevance and timeliness of this topic. For purely practical reasons, we argue and we encourage working on the authority physical activity teachers and especially on Tunisian physical education teachers.

\section{Method and Data Collection}

\subsection{Procedure}

Permission to conduct the current study by the University was Granted Institutional Review Board, the Tunisian 
Ministry of sports, the Principal of Higher Institute of sports and physical education (ISSEP) of Ksar Said in Tunis (Tunisia) (Manouba University). The researchers visited the cooperative teachers CT and PE-STs dyads in their respective schools in order to present the purpose and design of the research and obtain written informed approval.

This study presents an exploratory study in which were analyzed the perceptions that mentors and PESTT have about authority and to characterize the intervention and the advices enunciated by the mentors to help their PESTT in report with the indiscipline of their pupils.

The PESTT perceptions' about conduct problems encountered in the PES during the first training in education were identified. If the initial perceptions of future teachers interested many researchers (Calderhead \& Robson, 1991; Weinstein, 1990) and if the problems of beginning teachers during their first years of practice has been the subject of an important recession of fifteen years ago (Veenman, 1984), those experienced by students (those faced by students, those that students lives) during their first internship teaching.

\subsection{Participants}

- Mentors: 10 CT mentoring the PESTT had been freely accepted to participate in this study throughout the one scholar year training period. These CT had more than five years of experience in mentoring. All mentors having more than 5 years experience were men and had between 35 and 45 old years aged.

- PESTT: 24 PESTT in the initiation of practical pedagogy, at the Higher Institute of Sport and Physical Education (ISSEP) Ksar Saïd Tunis and supervised by the mentors participating at this study had been freely accepted to participate at this research. They were enrolled in the same training program as part of the preparation course to professional life in the last year of study for the graduation of Fundamental License of Physical Education in Tunisia (Bac +3$)$. They were men and average age of 21 years \pm 1 year old. This course is organized in colleges at the rate of four teaching hours per week for each PESTT, and this, on a school year.

They were teaching at a school in Tunis with mixed classes (aged 12 - 14). In this interschip, PESTT attended 4 hours of teaching every week during one scholar year. Hence the term "Physical Educational Student Teacher" that we adopted in this study.

\subsection{Method}

The method used is based on an "in situ" observation and taking notes about t case of indiscipline of 24 Physical Education Sessions (PES) supervised by 10 mentors participating in this study, and semi-structured individually interview made with all participants in this study (10 mentors and 24 PESTT) in initiation to teaching practice, practicing at the ISSEP Ksar Saïd Tunis, Manouba University, Tunisia. After the sessions observing teaching practices of PESTT 60mn duration (step 1), semi-structured interviews were conducted with each of these PESTT observed and recorded. These interviews were conducted with ten mentors working at the ISSEP (step 2). Given the nature of the research, all the interviews conducted with PESTT were semi-structured interviews. Accordance with the principles of the semi-directive interview (Mucchielli, 1976), the interview guide may slightly change due to data collected by the observations of teaching practices in these subjects interviewed but without deviating from the main thesis. The duration was scheduled for 40 minutes, according to the same considerations, the duration varied slightly from one subject to another.

We used a Dictaphone to record the responses of mentors interviewed. The questions focus on specific teaching practices previously recorded subjects interviewed. PESTT are interviewed while leaving freedom of speech they can express themselves at their ease.

We then proceeded to the transcription (step 3) of audio recordings of semi-structured interviews individually established after the observation of each teacher to create the corpus and we reported in the grid (Table 1) developed by the researcher (step 4). This grid allowed us to categorize (step 5) the mentors' perception of PESTT authorities.

\subsection{Data Collection}

Data were collected in three phases during 2 months. The first is a pre-interview with 15 mentors to constitute their biography data, such as the number of years of experience in mentoring and we asked them if they will accept to participate at this research. Twelve of them had freely accepted to participate at this study. At this meeting we presented to the mentors the various stages of this research such as a semi-directive interview related ses- 
Table 1. The cooperative teachers conceptions’ about student teachers’ authority.

\begin{tabular}{|c|c|c|}
\hline & A teacher-centered pedagogy $77.31 \%$ & $\%$ \\
\hline \multirow{8}{*}{$\begin{array}{l}\text { Observation: What the PESTT do? } \\
\qquad \mathrm{N}=194\end{array}$} & Screaming, panicking & $25.33 \%$ \\
\hline & Expel from the course & $19.33 \%$ \\
\hline & Firmness pedagogical attitude & $4.66 \%$ \\
\hline & Punishing last recourse & $8 \%$ \\
\hline & Teacher's personality & $10 \%$ \\
\hline & Excessive authority & $18.66 \%$ \\
\hline & Nonchalance, shyness & $6 \%$ \\
\hline & Stressed and afraid & $9.33 \%$ \\
\hline \multicolumn{2}{|c|}{ A pupil-centered pedagogy $22.69 \%$} & $\%$ \\
\hline \multicolumn{2}{|c|}{ Identify leaders } & $18.18 \%$ \\
\hline \multicolumn{2}{|c|}{ Paying attention to pupils } & $25 \%$ \\
\hline \multicolumn{2}{|c|}{ Identify their pupils } & $9.09 \%$ \\
\hline \multicolumn{2}{|c|}{ Knowing their names } & $13.63 \%$ \\
\hline \multicolumn{2}{|c|}{ Dealing with them Individually } & $7 \%$ \\
\hline \multicolumn{2}{|c|}{ Lack of concentration } & $5 \%$ \\
\hline \multicolumn{2}{|c|}{ Interesting pupils } & $22.72 \%$ \\
\hline
\end{tabular}

sion recorded representing three phases of the data collection. They gave PESTT and their mentors an opportunity to share their perspectives on broad topics such as education, teaching, and society, and also on more succinct topics such as individual students and situations that had occurred in previous lessons. Our data were analyzed using constant comparison (Berelson, 1952; Buron, 2000). Two themes were emerged to show how PESTT manage authority and how there are helped by their didactic and pedagogical manoeuvring during lessons.

\section{Result}

In the following sections, we present the results for each research question and summarize the variety and accuracies. We then discuss the findings and consider implications for teacher education program. Analyses of the interviews with 12CT showed that their assessment centered on the issues of interpersonal relationships, power sharing, and tension and conflict. The central concept of a non-authoritative approach to supervision of student teachers that embraces relationship issues rose by the participants and provides successful learning experiences for PESTT.

Table 1 shows the correlations, percentage of accurate predictions for each category. As summarized earlier in Table 1, the data collected is grouped into two categories: a teacher-centred pedagogy (77.31\%) and a pupilcentred pedagogy (22.69\%).

The results presented in this paper about PEST encourages interrogating their ability to manage their PES effectively. The answers that we have identified in the question "How mentors proceed spontaneously with their students?” had showed that mentors conceptions' of the PEST's intervention is centred on the teacher (77.31\%). They adopt spontaneously a teacher-centred pedagogy: they screaming and panicking (25.33\%). One CT interviewed reports that:

"Thereafter, the student does not care about the child and does not take into account that the child is the centre of pedagogy, there is no use of his own psychomotor responses” (CT6).

One CT said:

“The students' problem is that they are struggling to move from the student status to the teacher status with all the responsibility behind! For me, the most fundamental thing is the organization before, during and after the course" (CT9). 
Table 2. CT advices to learn class management skill.

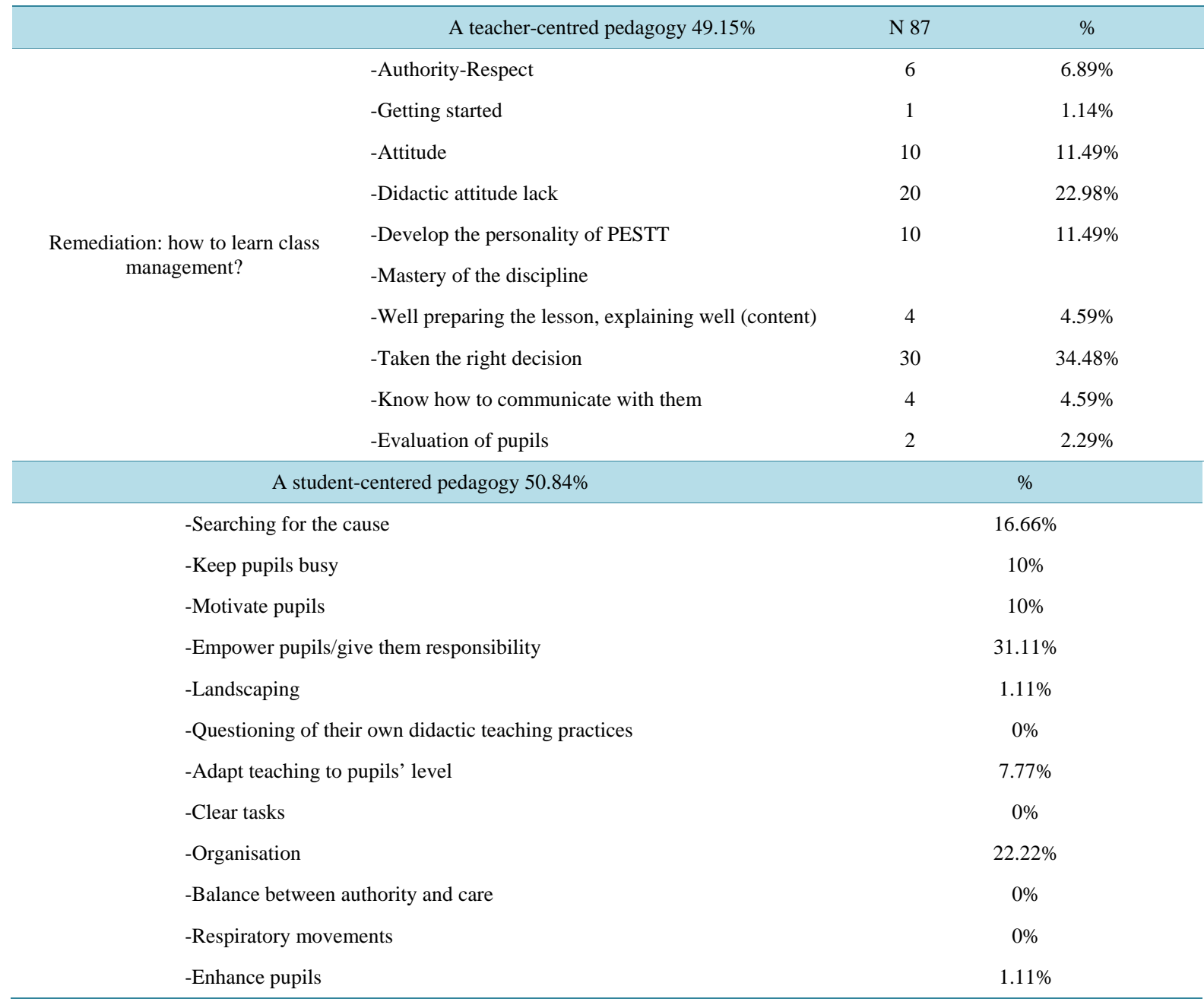

There are also severe even quarrelsome with their students, exclude them from the field (19.33\%) when they exaggerate.

"The session beginning the first place: the success criteria. The students should be careful but how? For example, the respiratory movement: the fact to breathe relaxes and it enables students to concentrate better. It is a pedagogical tool! So the getting started is very important" (CT9).

These seem to use in their majority, the excessive authority (18.66\%) to manage the discipline in the classroom.

"The students must adopt a pedagogical approach allowing to them to master the class voice placement in relation to their students...” (CT4).

Robbes (2004) explains that this authority occupies a considerable place in the educational process: “... the authority is essentially educational. The authority is synonymous with education". By the verbs "to be", "have" and "do" Robbes (2004) defines three reports to the authority "to be the authority", "have authority" and "do authority" that alternate during the teacher's action in the classroom. Thus, he considers that the authority plays a fundamental role in the educational process, and says: "mutual, negotiated, the recognition constitutes the key element of the process of authority legitimating” Robbes (2004).

Some PEST, panic and lose control of the situation (25.33\%) when the discipline degenerates and will seek the help and the intervention of their mentors. One of CT had said: 
"For example, a student came to ask me how to act face a student who says rude words" (CT8).

"This is a lack of authority on the part of students because these beginners, unless if the student is really has a strong character and has a very strong personality. But it is a rare quality among the beginners! So I had to call the student and I reprimand him!” (CT7).

They generally use excessive authority (19.33\%). This is explained as much by their lack of experience (this is the first time they load instruction), by the example that they hold from their own teachers (Bali, 2005).

"Generally and unfortunately, students use excessive authority on the field" (CT5).

"The sanction is the last resort after changing mind (the sanction exists but it must be used as a last resort" (CT8).

Several authors argue that higher education physical education initial teacher training in England fails to recognise and accommodate the needs of disturb students' behaviour, creating barriers to the profession and perpetuating the cycle of exclusion from the teaching profession. One CT had revealed to us:

"Because unfortunately, the majority of students in the next generation or the beginners in general use the excessive authority in the field: it is the teaching by commandment! Why? Because they:

-do not master the knowledge.

- Think that being authoritarian, students will apply.

-Present the task, correct and try to find solutions to the problems" (CT10).

CT report also that some PEST adopt a teaching-centred pedagogy (22.69\%): they pay attention to their pupils (25\%), call them by their name, identify leaders (18.18\%) and occupy rewarding tasks interesting pupils (22.72\%).

"The Cognitive axis: because we live in a society where we respect his superior, his father, his teacher... and we should not act at the same way with everyone!” (CT3).

To the question: "How do the mentors think helping their PEST to better manage the discipliner's situation? We have identified two categories that can be classified as action centred on the teacher and action focused on pupils in almost equal proportions.

Indeed, $49.15 \%$ of the advices given by CT to PEST teachers suggest remedial pedagogy centred on the teacher:

- Prepare his lessons (17\%):

"The students must adopt a pedagogical approach allowing to them to master the class: voice, placement in relation to their students, landscaping, and lesson content" (CT10).

“... They must well present the task, well explain it...” (CT3).

- Require teacher's respect (15\%):

"The trainee must be heard by his students without a power it is a relationship of respect" (СT9).

"The student must be respected by his pupils" (CT10).

"He must avoid nonchalance; otherwise he will not happen to be respected" (CT1).

"The trainee must be heard by the students" (CT3).

- And make appropriate decisions (13\%):

"First I present to them the qualities of a teacher such as radiation, ease, authority, presence..." (CT3).

“... As against a hesitant student or teacher, who gropes, who can not make a decision, who did not prepare his lesson, all these elements could be disruptive elements of the course! (Students will not be concentrated)!” (CT2).

Additional issues reported in the physical education literature cite the low status of physical education and the lack of respect given to the profession by members of the school community (McCormack \& Thomas, 2003b; Schempp, Sparkes, \& Templin, 1993), physical isolation within the school setting, fewer colleagues available for support, and a lack of appropriate resources or teaching space (McCormack \& Thomas, 2003b). However, $50.78 \%$ of other advices given to the PEST suggest remedial pedagogy centred on the students that we are regrouped in different items: 
- Locate the cause of the discipline (14\%):

"For example, I have a lackadaisical student, who even if it overflows with accident risk, she makes even not count and it's up to me to intervene and restore the order in the class!” (CT4).

- Valorising his students (12\%):

"So the discipline in the classroom depends on the trainee attitude, that's why the session started and authority are very important" (CT2).

"If there is indiscipline, it is the pupil who is not well educated. The indiscipline does not depend on the teacher or his content. For ST, it is because the pupils are not well educated" (CT1).

- Motivate them and (15\%), occupy them throughout the session (12\%):

"he panics and continues to scream but without doing nothing to solve the problem" (CT3).

"Thus, so long as he did not seek the reason of the indiscipline problem, she will never solve this problem" (CT4).

- Organizing his teaching by adjusting material, adapt his teachings, clarity of the instruction... (20\%):

"But the student never thinks that it's the content which does not attract the pupil attention or that the pupil is bored or he is into a risked pedagogical situation which is not adapted to his level..." (CT2).

"The trainee must assume responsibility. He is the responsible: he must search the error cause, that's to say why the pupil did this or that? Because ST were too firm or too cool!" (CT6).

"It is the origin of the organization and not authority" (CT3).

"If you want to change their frame of mind and get them to understand why the indiscipline indexes occur, he should think on hiss lesson content, his pedagogical attitude, his behavior, the class organization... Transfer the reflection from the student to the teacher" (CT7).

It is in this case, as said this French pedagogue of the 20th century "to organize the teachings for that the discipline is respected” (Freinet, 1952).

\section{Cooperative Teachers and PEST Conceptions' about Indiscipline}

Data of Table 3 have revealed the mentors authority conceptions that refer to what they qualify themselves of "natural authority". The natural authority is considered as an authority not exercised, it is felt and perceived by students without that the teacher is able to recall it or exercise it. The majority of PEST returns the responsibility of these cases of indiscipline on the field to students during their didactic interventions. They said that indiscipline is because three main reasons: 1) Students are not well educated (42\%); 2) Students are not interested (35\%); 3) Students are not concentrated (23\%) (Bali, 2012). Indeed, the first researches that have focused on the question of managing discipline in classroom were conducted in a linear fashion; the rupture of this order is the fault of the student (Jones \& Jones, 1981). Then, the researches that have been conducted return the responsibility both to the student in his report to the rule (Latz, 1992; Méard et al., 1996; Bertone et al., 2002) or students' incivility. The authority constitute a pedagogical preoccupation for the novice teacher (Dussaussois, 1997), in his capacity to ensure this requirement at the beginning of the scholar year, the authority represents an professionalization issue which pass necessarily through skills development, and is observed through professional actions

Table 3. Comparative pedagogy intervention.

\begin{tabular}{ccc}
\hline & Pedagogy centered on teacher & Pedagogy centered on pupils \\
\hline Conceptions & 150 & 44 \\
Remediation & 87 & 90 \\
\hline & Global & Analytique \\
\hline KHI2 & 28.5957 & 31.8257 \\
DDL & 1 & 1 \\
Decision & T.S $P<0.001$ & T.S $P<0.001$ \\
$P$ & 0.0000 & 0.0000 \\
\hline
\end{tabular}


(Jorro, 2002) that organize the teacher’s action.

\section{Discussion}

Our findings indicate that in the majority of cases (63.5\%), supervisors' predictions were within 5 points of the candidate's total score on the PACT teaching event. However, in some cases, predictions and scores were within 5 points but differed on other dimensions such as pass/fail designation.

Darling-Hammond et al. (2002) was also studied the relationship between teacher feelings and perceptions and teacher retention. Assessments of a teachers' effectiveness can be used to judge teachers' instructional ability (Sindelar, Daunic, \& Rennells, 2004) and can lead a school leader to fire the teacher. However, most teacher turnover is voluntary (Thin, 2002; Marvel et al., 2007). Increasingly, teachers' subjective assessments of their impact on student learning, such as whether they feel a sense of success (Johnson \& Birkeland, 2003), their sense of self-efficacy (Yost, 2006), and their sense of personal power (Moscovici, 2009), have been found to influence teacher career decisions. The results presented in this article about PEST encourages interrogating their ability to manage their PES effectively. The answers that we have identified in the question "How mentors proceed spontaneously with their students?" had showed that mentors conceptions' of the PEST's intervention is centred on the teacher (77.31\%). They adopt spontaneously a teacher-centred pedagogy: they screaming and panicking (25.33\%). There are also severe even quarrelsome with their students, exclude them from the field $(19.33 \%)$ when they exaggerate. These seem to use in their majority, the excessive authority (18.66\%) to man age the discipline in the classroom. Robbes (2004) attest that authority is necessary in the educational process. According to him authority and education are equal.

Also, Robbes (2004) says that authority is fundamental and it's common and it's permanent during the teaching process in a practical session. Thus, he considers that the authority plays a majorpart in the educational process.

Some PEST, panic and lose control of the situation (25.33\%) when the discipline degenerates and will seek the help and the intervention of their mentors. They generally use excessive authority (19.33\%). This is explained as much by their lack of experience, (this is the first time they load instruction), by the example that they hold from their own teachers (Bali, 2005; Bali, 2013). Several authors argue that higher education physical education initial teacher training in England fails to recognize and accommodate the needs of disturb students' behaviour, creating barriers to the profession and perpetuating the cycle of exclusion from the teaching profession (Fernandez-Balboa, 1990; Dussaussois, 1997; Flavier, 2002).

The mentors report also that some PESTT adopt a student-centred pedagogy (22.69\%): they pay attention to their pupils (25\%), call them by their name, identify leaders (18.18\%) and occupy rewarding tasks interesting pupils (22.72\%). To the question: How do the mentors think helping their PESTT to better manage the disciplinary situation? We have identified two categories that can be classified as action centred on the teacher and action focused on pupils in almost equal proportions. Indeed, $49.15 \%$ of the advices given by the monitors to the PESTT teachers suggest remedial pedagogy centred on the teacher: prepare his lessons (17\%), require teacher's respect (15\%) and make appropriate decisions (13\%). Additional issues reported in the physical education literature cite the low status of physical education and the lack of respect given to the profession by members of the school community (McCormack \& Thomas, 2003b; Schempp, Sparkes, \& Templin, 1993), physical isolation within the school setting, fewer colleagues available for support, and a lack of appropriate resources or teaching space (McCormack \& Thomas, 2003b). However, 50.78\% of the advices given to the PEST suggest remedial pedagogy centered on the students: locate the cause of the discipline (14\%), valorising his students (12\%), motivate them (15\%), occupy them throughout the session (12\%), organizing his teaching by adjusting material , adapt his teachings, clarity of the instruction... (20\%). It is in this case, as repeated this French pedagogue of the 20th century "to organize the teachings for that the discipline is respected (Freinet, 1952). In the continuity of analyze, we have revealed among the mentors authority conceptions that refer to what they qualify themselves of "natural authority". The natural authority is considered as an authority not exercised, it is felt and perceived by students without that the teacher is able to recall it or exercise it. However, in their interventions, the majority of the PEST returns the responsibility of these cases of indiscipline on the field to students. They explain indiscipline on the practical session of PE as follows: 1) Students are not well educated (42\%), 2) Students are not interested (35\%); 3) Students are not concentrated (23\%). Indeed, the first researches that have focused on the question of managing discipline in classroom were conducted in a linear fashion; the rupture of this order is the 
fault of the student (Jones \& Jones, 1981). Then, the researches that have been conducted return the responsibility both to the student in his report to the rule (Méard \& Bretone, 1996) or students' incivility. The authority constitute a pedagogical preoccupation for the novice teacher (Dussaussois, 1997), in his capacity to ensure this requirement at the beginning of the scholar year, the authority represents an professionalization issue which pass necessarily through skills development, and is observed through professional actions (Jorro, 2002) that organize the teacher's action. Fernand Oury (1995) said that "the authoritative is not authoritarian". The skill of the master does the authority and this one results in actions, observable by students". Making authority is probably the most important dimension in authority, because it gives shape to the other two dimensions, the status and subject author (who has enough confidence in himself to grow another). The educational authority is daring relationship to the other, goes after the resolution of a conflict, and does not drop its mission with students.

What psycho-pedagogic researchers say about the use of authority in the classroom?

In his book "Education in search of a new authority", Imbert (1989) warns that any abuse of authority inhibits learning, by preventing the creation of a classroom climate friendly and serene, in which everyone can learn at ease. Indeed, an authoritarian teacher can scare students, but does not favorite their learning, because learning new skills is a cognitive activity that needs serenity, freedom... Imbert (1996) also points out that the real authority is not an authority based on violence or fear, but rather an authority that derives its legitimacy from the scientific and pedagogical competence of the teacher and his ability to motivate students and occupy them. To be respected, a teacher must be perceived by students as a credible professional (scientifically, educationally and morally). However, because of its status and its early entry into professional life, a trainee teacher is vulnerable and finds many difficulties in his speech (Martineau, 2003).

Roger Cousinet. Former teacher became primary; Inspector is one of the first partisans of the experimental approach, related to a learning pedagogy. The child learns best when his attention will be motivated each time by a concrete goal that we have proposed to him. We need to build the knowledge; the master must not expose his knowledge, but must work with the child. "We can no longer teach, but learn" This is what the inspector advises. Similarly, it favours the group work, so that a community life is organized in his students, and that they join by themselves in a socialization process. Related to the other international pedagogical experience, Cousinet has made an innovation that constitute a kind of crucible for Freinet pedagogy. Only two elements oppose them, and make Freinet pedagogy the original: unlike Cousinet, who thinks that it is not the game that encourages the child to learn, if teaching knows to be attractive. Freinet rejects the game as a learning form. The Work that knows arouse the child's interest is at the heart of Freinet pedagogy. One thinks that it is easier to learn for a child if the acquisition passes through the game and the organization of recreational activities. The other argues that it is not the game that is natural in children, but the work, and that it must therefore be organized. The game should not lead to learn, but the work must reach be a game. What differentiates them is also the way how they approach the pedagogy: Cousinet, as an inspector can only theorize about the new school, Freinet can experience his method in his classroom.

The results "as shown in Table 3" of the empirical survey conducted among the mentors of the PEST show that these seem to use in their majority, the excessive authority during their teaching session to manage discipline in the classroom. Accordingly to Robbes (2004), this authority occupies a considerable place in the educational process: “ $\ldots$ the authority is essentially educative. The authority is synonymous with education”. By the verbs "to be", "have" and "do" Robbes (2004) defines three reports to the authority "to be the authority", "have authority" and "do authority" that alternate during the teacher's action in the classroom. Thus, he considers that the authority plays a fundamental role in the educational process, and says: "mutual, negotiated, the recognition constitutes the key element of the process of authority legitimating” (Robbes, 2004). Teaching is a profession that requires flexibility, a practice exercised in the uncertainty. However, according to the statements of these mentors, the majority of the PEST seems to manage the discipline in the practical session using a teacher-centred pedagogy. This is explained as much by their lack of experience, (this is the first time they load instruction) and by the example that they hold from their own teachers (Bali, 2005; Bali, 2013; Bali et al., 2013). How the PEST may be able to develop professional skills that will lead him to identify and solve the problems in such complex area that is education in general and physical education in particular. Indeed, this is what (Allec \& Jorro, 2008) qualifies by "being authoritarian" that is traduced the social and psychological affirmation of the individual toward the others or take again (in case of breakage) the control of the situation and put an end to the drifts. Thus, authors were interested to the concept of authority in order to formalize to make it accessible to the 
field of the professional training. Therefore, this exceeds the narrow limits of the discipline to reach the whole training of these PEST. While in the theoretical courses we remind them of the need to put the learner at the center of the teaching learning process, it seems that the pedagogy practiced by their teachers, show them models centered on the teacher. Again, it is to reconcile the theoretical training with practical training (Bali, 2005; Bali, 2013). This is that (Allec \& Jorro, 2008) qualifies by "being authoritarian” that is traduced by the social and psychological affirmation of the individual toward the others or take again the control of the situation. More concretely, teacher authority is the result of students' recognition of the skills he displays in action. Such skills pass inevitably trough the operationalization of its disciplinary, pedagogical and relational knowledge's. "Teacher authority is not natural but (...) results from a knowledge construction in action. The teacher is faced to the question of 'how to do?' that is to say to the actions knowledge's that it engages in the practice of educational authority” (Allec, 2008).

\section{Comparison between CT Conceptions and PEST Conceptions about Indiscipline}

The result of CT and PEST conceptions about indiscipline revealed that they thought that excessive authority is natural. In fact, the natural authority is an authority witch we not perceive and that the teacher enforced without realizing that he is authoritative.

However, in their didactic practices, most of PEST argued that the pupils are the only responsible of these cases of indiscipline on physical education session. They said also and that the problem comes from their families. Dussaussois (1997) showed that managing class is the pedagogical priority of the novice teacher in his first year teaching. While some of the CT confirm that indiscipline in practical session is the fault of PEST. They don't well prepared their course and are not attentifs to their people. The other CTs, said that it's natural that ST can not be authoritarian because they are novice teacher and have no experience.

In fact, the education authority of the teacher is a bold relationship to another, just after the resolution of a conflict, and does not change his role with his students.

Also, Imbert (1996) puts forward that learning is promoted in a friendly and peaceful atmosphere, where everyone can learn at ease while abuse of authority can affect negatively learning. He argues that the natural authority is not an authority based on violence or fear, but rather an authority that derives its legitimacy from the scientific and pedagogical competence of the teacher and his ability to motivate students and to occupy them. To be respected, a teacher should be seen by students as credible professionally. However, Martineau (2003) confirms that, because of its status and its entry into the early job as a teacher, a student teacher is vulnerable and found many difficulties in his classroom management. By Roger Cousinet, Children learn best when attention is driven each time by a concrete target the teacher wants him. Likewise, it promotes the working group, so that students join themselves in a process of socialization. Unlike Cousinet who think this is not the game that encourages children to learn, work who knows arouse the child's interest is at the heart of the Freinet pedagogy. We think it is easier for a child to learn if the acquisition goes through the game and the organization of leisure activities. The other argues that this is not the game that is natural in children, but the work, and must therefore be organized. The game should not lead to learn, but the work must reach to be a play. What differentiates them is how they approach teaching.

\section{Conclusion}

Therefore, in this study we examined the role of the mentors to help their PEST to manage authority. In summary, the issue is complex, because some PEST say that it is still too soon or too late. This reaction is explained by the fact that during the initial training, as the PEST was not confronted with a problem on the practical session, it is not yet in the intellectual dispositions to integrate the contributions of the monitors who could help them. This does not exclude, thereafter, theoretical contributions or the study of teaching and learning situations more "consistent", encouraging the exercise of an educational authority. This occupation comes next, because it is "inaudible" for beginners, "stressed" by the management of the class everyday. According to my research, PESTT have fewer types of education coursework and shorter field experiences and feel less well prepared. Thus, new teacher career decisions are often driven by their perceptions of their effectiveness and other factors that relate directly to the quality of their preparation programs (Cohen et al., 1982; Johnson \& Birkeland, 2003; Moscovici, 2009; Yost, 2006; Bali et al., 2014). 


\section{References}

Alin, C. H. (2009). La construction identitaire de l'enseignant. Le rôle des métaphores. Recherche et Formation, 47, 41-54.

Allec, S., \& Jorro (2008). Les caractéristiques et les enjeux pédagogiques de la relation à l'autorité dans l'enseignement de l'EPS: De la modélisation du concept à la formalisation de compétences professionnelles. Exemple d'application dans l'analyse des pratiques du professeur novice. Thèse de Doctorat non publiée, Toulouse: Université de Toulouse II.

Bali, N. (2005). Articulation "théorie-pratique” dans la formation des élèves-professeurs tunisiens d'éducation physique. Recherche et Formation, 49, 135-150.

Bali, N. (2013). Teachers’ Thought Processes: The Case of Tunisian Gymnastic University Teachers. Creative Education, 4, 158-164. http://dx.doi.org/10.4236/ce.2013.47A2020

Bali, N. et al. (2013). The Proceed of Thinking Surrounded by Some French and Tunisian Gymnastic Teachers. IOSR Journal of Research \& Method in Education (IOSR-JRME), 2, 17-24. http://dx.doi.org/10.9790/7388-0221724

Bali, N. et al. (2014). The Conceptions of Integration of Tunisian Physical Education Cooperative Teachers and Student Teachers. Creative Education, 5, 279-289. http://dx.doi.org/10.4236/ce.2014.54037

Berelson, B. (1952) Content Analysis. In G. Lindsey (Ed.), Handbook of Social Psychology (p. 1954). Readings: Addison Wesley.

Bertone, S. et al. (2002). Undisciplined Actions and Teacher-Student Transactions during Two Physical Education Lessons. European Physical Education Review (UK), 2, 4-21.

Calderhead, J., \& Robson, M. (1991). Images of Teaching: Student Teachers Early Conceptions of Classroom Practice. Teaching and Teacher Education, 7, 1-8. http://dx.doi.org/10.1016/0742-051X(91)90053-R

Cohen, P. A. et al. (1982). Educational Outcomes of Tutoring: A Meta-Analysis of Findings. American Educational Research Journal, 19, 237-248. http://dx.doi.org/10.3102/00028312019002237

Cruickshank, D. R., Kennedy, J. J., \& Myers, B. (1974). Perceived Problems of Secondary School Teachers. The Journal of Educational Research, 154-159.

Darling-Hammond, L., \& Youngs, P. (2002). Defining “Highly Qualified Teachers”: What Does “Scientifically-Based Research” Actually Tell Us? Educational Researcher, 13-25.

Dussaussois, D. (1997). Pourvu qu'ils m'écoutent... Discipline et autorité dans la classe. Le Perreux-sur-Marne: CRDP Créteil.

Fernandez-Balboa, J. M. (1990). Helping Novice Teachers Handle Discipline Problems. Journal of Physical Education, Recreation \& Dance, 61, 50-54. http://dx.doi.org/10.1080/07303084.1990.10604580

Flavier, E., Bertone, S., Méard, J., \& Durand, M. (2002). The Meaning and Organization of Physical Education Teachers' Action during Conflict Which Opposes Them with Student(s). Journal of Teaching in Physical Education (US), $22,20-38$.

Freinet, C. (1952). Les techniques Freinet de l'Ecole Moderne. PUF.

Fuller, F., \& Brown, O. (1975). Becoming a Teacher. In K. Ryan (Ed.), Seventy-Fourth Year Book of the National Society for the Study of Education: Pt. 2. Teacher Education.

Good, T. L., \& Brophy (1987). Two Decades of Research on Teacher Expectations: Findings and Future Directions. Journal of Teacher Education, 38, 32-47.

Herbert, K. S., \& Ramsay, M. C. (2004). Teacher Turnover and Shortages of Qualified Teachers in Texas Public School Districts. Retrieved March, 23, 2009.

Imbert, F. (1996). L’inconscient dans la classe. Transferts et contre-transferts. Revue française de pédagogie, 117, $165-168$.

Johnson, S., \& Birkeland, S. (2003). Pursuing a "Sense of Success”: New Teachers Explain Their Career Decisions. American Educational Research Journal, 40, 581-617.

Jones, V. F., \& Jones, L. S. (1981). Comprehensive Classroom Management. Boston, MA: Allyn et Bacon.

Jorro, A. (2002). Réflexivité et auto-évaluation dans les pratiques enseignantes. Revue Mesure et évaluation en éducation, 27.

Kim, T., \& Danforth, S. (2012). Non-Authoritative Approach to Supervision of Student Teachers: Cooperating Teachers' Conceptual Metaphors. Journal of Education for Teaching, 38, 67-82.

Latz, M. (1992). Preservice Teachers’ Perceptions and Concerns about Classroom Management and Discipline: A Qualitative Investigation. Journal of Science Teacher Education, 3, 1-4. http://dx.doi.org/10.1007/BF02614729

Legault, F. (1999). La gestion de la classe durant un stage d'initiation à l'enseignement et l'émergence d'une communauté virtuelle axée sur la résolution de problème. Revue des sciences de l'éducation, 25, 593-618.

http://dx.doi.org/10.7202/032015ar 
Leinhardt, G. (2001). Instructional Explanations: A Commonplace for Teaching and Location for Contrast. Handbook of Research on Teaching, 4, 333-357.

Martineau, S. (2003). Le sentiment d'incompétence pédagogique des enseignants en début de carrière et le soutien à l'insertion professionnelle. Brock Education Journal, 12, 54-67.

Martineau, S., \& Corriveau, G. (2000). Vers une meilleure compréhension du sentiment d'incompétence pédagogique chez les enseignants en insertion professionnelle au secondaire. Formation et profession, 6, 5-8.

Marvel, J., Lyter, D. M., Peltola, P., Strizek, G. A., Morton, B. A., \& Rowland, R. (2007). Teacher Attrition and Mobility: Results from the 2004-05 Teacher Follow-Up Survey. NCES 2007-307. National Center for Education Statistics.

McCormack, A., Gore, J., \& Thomas, K. (2006). Early Career Teacher Professional Learning. Asia-Pacific Journal of Teacher Education, 34, 95-113.

Méard, J., Bertone, S., \& Euzet, J. P. (1996). Comment les professeurs d'éducation physique et sportive transforment les attitudes de leurs élèves. Education et Recherche $(\mathrm{CH}), 1$, 79-92.

Michaud, C., \& Alin, C. (2009). Processus Portfolio: De la réflexivité à la compétence. In Acte du 21ième colloque ADMEE-Europe Evaluation et Développement professionnel-UC Louvain la Neuve-21 au (Vol. 23).

Moscovici, S. (2009). Préface. In Le partage social des émotions (pp. XI-XVI). Presses Universitaires de France. www.cairn.info/le-partage-social-des-emotions--9782130578543-page-XI.htm

Odell, S. J., \& Ferraro, D. P. (1992). Teacher Mentoring and Teacher Retention. Journal of Teacher Education, 43, $200-204$.

Oury, F. (1995). Pédagogie institutionnelle. Vigneux, Editions Matrice.

Pigge, F. L. (1978). Teacher Competencies: Need, Proficiency, and Where Proficiency Was Developed. Journal of Teacher Education, 29, 70-76.

Piot, T. (2008). Building Teaching Competencies. McGill Journal of Education, 43.

Robbes, B. (2004). Se défaire de l'autoritaire. In L'autorité. Paris: Cahiers pédagogique, no. 426.

Robbes, B. (2006). L'autorité de l'enseignant comme savoir d'action, nouvelle prévention des violences en milieu scolaire? Spirale, 37, 111-122.

Sindelar, P. T., Daunic, A., \& Rennells, M. S. (2004). Comparisons of Traditionally and Alternatively Trained Teachers. Exceptionality, 12, 209-223.

Tardif, M., \& Lessard, C. (1999). L'enseignement au quotidien. Sainte-Foy: Presses de l’Université Laval.

Thin, D. (2002). L'autorité pédagogique en question. Le cas des collèges de quartiers populaires. INRP, Revue française de Pédagogie, 139, 21-30.

Turner, J. C., \& Meyer, D. K. (2000). Studying and Understanding the Instructional Contexts of Classrooms: Using Our Past to Forge Our Future. Educational Psychologist, 35, 69-85.

Veenman, S. (1984). Perceived Problems of Beginning Teachers. Review of Educational Research, 54, 143-178.

Weinstein, C. S. (1990). Prospective Elementary Teachers’ Beliefs about Teaching: Implications for Teacher Education. Teaching and Teacher Education, 6, 279-290.

Woolfolk, A. E., \& Hoy, W. K. (1990). Prospective Teachers' Sense of Efficacy and Beliefs about Control. Journal of educational Psychology, 82, 81.

Zeichner, K. G., \& Gore, Y. J. (1990). Teacher Socialization. In Handbook of Research on Teacher Education (pp. 329-348). New York: MacMillan. 
Scientific Research Publishing (SCIRP) is one of the largest Open Access journal publishers. It is currently publishing more than 200 open access, online, peer-reviewed journals covering a wide range of academic disciplines. SCIRP serves the worldwide academic communities and contributes to the progress and application of science with its publication.

Other selected journals from SCIRP are listed as below. Submit your manuscript to us via either submit@scirp.org or Online Submission Portal.
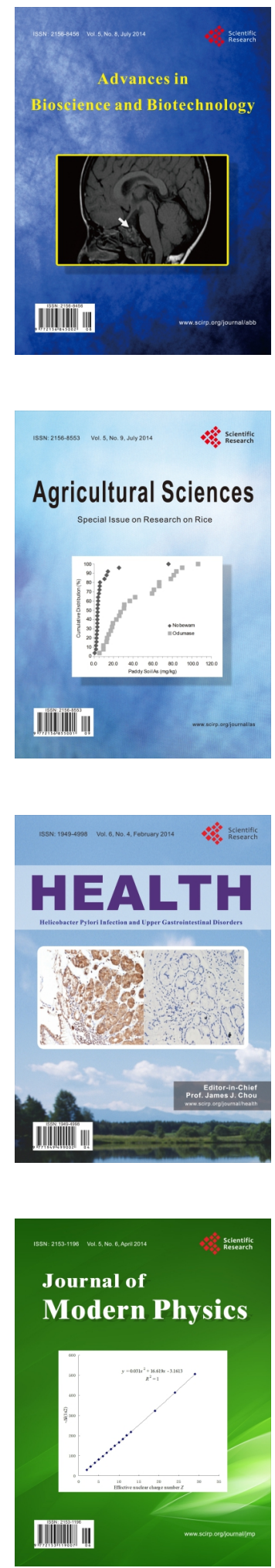
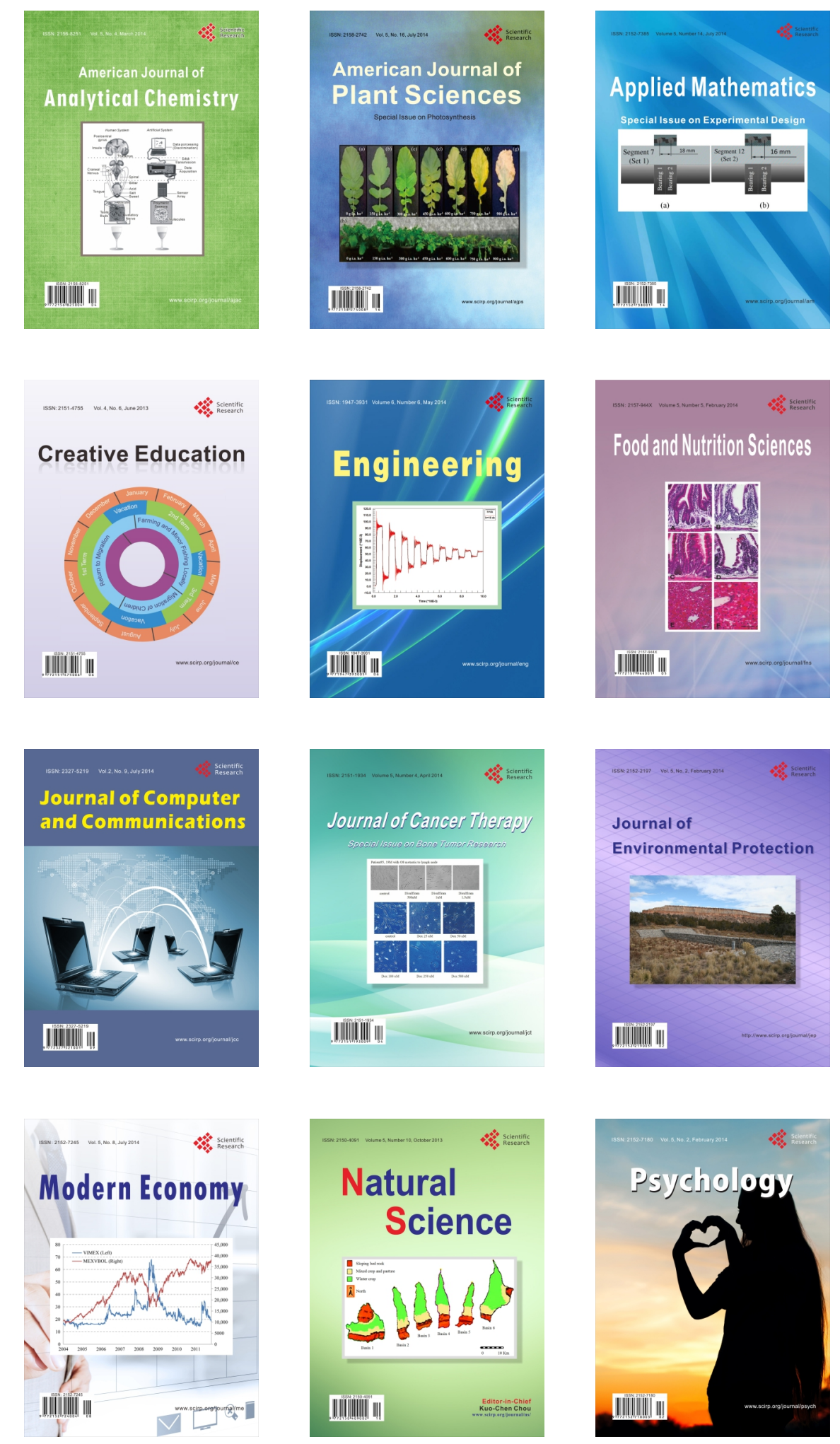